\title{
Midcervical central cord syndrome: numb and clumsy hands due to midline cervical disc protrusion at the C3-4 intervertebral level
}

\author{
Masashi Nakajima, Keizo Hirayama
}

\begin{abstract}
Eight patients with midline cervical disc protrusion at the $\mathrm{C3}-4$ intervertebral level showed unusual clinical signs: numbness in the finger tips and palms, clumsiness of the hands, and a tightening sensation at the midthoracic level. The proprioceptive and cutaneous sensory afferents essential for motor control of the upper limbs were preferentially involved, tactile discrimination of passively given stimuli being spared. Somatosensory evoked potentials subsequent to median nerve stimulation showed conduction failure through the fasciculus cuneatus, as evidenced by absent or delayed and attenuated medullary and scalp potentials. The potential originating in the lower cervical cord (N13a) had a low amplitude, indicative of the caudal extension of the lesion. On the basis of the functional anatomy of the intraspinal pathways, especially of the dorsal columns, it is concluded that involvement of the central cord at the C3-4 intervertebral level and its caudal extension is responsible for the syndrome.
\end{abstract}

(F Neurol Neurosurg Psychiatry 1995;58:607-613)

Keywords: numb and clumsy hands; C3-4 disc; central cord syndrome

"Numb and clumsy hands" has been described as a sign of high cervical spinal cord compression, ${ }^{1-5}$ but whether selective involvement of lower cervical segments may be caused by a higher lesion is not clear. We investigated the transverse and longitudinal extent of cord lesions clinically and electrophysiologically in eight patients who had numb and clumsy hands due to midline cervical disc protrusion at C3-4.

Department of

Neurology, School of Medicine, Chiba University, 1-8-1 Inohana Chuo-ku, Chiba 260, Japan M Nakajima

K Hirayama

Correspondence to: Dr Masashi Nakajima, Department of Neurology, School of Medicine, Chiba University, 1-8-1 Inohana Chuo-ku, Chiba 260, Japan. Received 31 May 1994 and in revised form 20 October 1994.

Accepted 14 December 1994 up a coin in a pocket. In the later stage of the condition, seven patients noticed tight, band like sensations of deep pain at the midthoracic level that were circumferential in three and frontal in four. Neck pain that occasionally radiated to the back was experienced by three patients. Five complained of unsteady gait, which was severe enough that patient 2 required assistance; the others did not.

Horner's syndrome was present in six of the patients and two had acrocyanosis. Sensory and motor impairment that essentially was symmetric, predominated in the upper limbs. Pin prick and thermal sensations were mildly diminished below the $\mathrm{C} 3$ dermatome. Hypoalgesia occasionally was limited to the lower cervical segments. Impairment of crude touch and vibration predominated in the hands, but sometimes occurred up to the shoulders. Atrophy of the shoulder girdle and hands was noted in patient 4 . Details of the hand dysfunctions are given in the results.

In the lower limbs, vibration sense was preferentially impaired. Diminished pain sensation, weakness, and ataxia were present in various combinations. These long tract signs were mild when present, except for the ataxia of patient 2. Bladder disturbances were absent, except for patient 3, who had frequent urination. Muscle stretch reflexes were exaggerated below the cervical segments in five of the patients, but were normal in patient 1 and diminished in patient 2. Patient 6 had exaggerated finger jerks but normal reflexes in the lower limbs.

All the patients showed a midline cervical disc protrusion at C3-4 with or without spondylotic changes on myelography or MRI. Spinal cord compression was anteroposterior at this level (fig $1 \mathrm{~A}$ left and $1 \mathrm{~B}$ ), being massive in five and moderate in three of the patients. At the lower cervical level, five patients had mild spondylotic cord compression, the other three having no pathological findings. Electromyography showed chronic denervation of the $\mathrm{C} 5$ innervated muscles in five patients, two of whom had changes that extended to the lower cervical segments. Patient 7 had neurogenic changes in the lower C8 rather than in $\mathrm{C} 5$.

Anterior cervical discectomy and fusion at C3-4 was performed for four of the patients. The outcome was excellent for two, paraesthesia remaining only at the finger tips, and they became free from clumsiness of the hands. Patient 2, who had a history of neck trauma and had the most severe compression, could undertake independent daily activities 
Table 1 Clinical and laboratory findings

\begin{tabular}{|c|c|c|c|c|c|}
\hline \multirow{2}{*}{$\begin{array}{l}\text { Patient } \\
\text { Age/Sex }\end{array}$} & \multicolumn{2}{|l|}{ History } & \multicolumn{2}{|c|}{ Signs in the upper limbs } & \multirow{2}{*}{$\begin{array}{l}\text { Signs in the lower limbs } \\
\text { and bladder }\end{array}$} \\
\hline & Onset & Evolution & Hypoalgesia & Others & \\
\hline $153 \mathrm{y} / \mathrm{F}$ & $\begin{array}{l}\text { Numbness of finger } \\
\text { tips }\end{array}$ & $\begin{array}{l}\text { Clumsiness of hands, tight band at } \\
\mathrm{T} 5 \text {, for } 4 \text { months }\end{array}$ & $\mathrm{C} 3-\mathrm{C} 8$ & $\begin{array}{l}\text { Diminished vibration in } \\
\text { hands }\end{array}$ & Abolished vibration \\
\hline $28 \mathrm{y} / \mathrm{M}$ & $\begin{array}{l}\text { Numbness of } \\
\text { palms and soles } 2 \\
\text { months after neck } \\
\text { trauma }\end{array}$ & $\begin{array}{l}\text { Clumsiness of hands, gait } \\
\text { unsteadiness, tightness in abdomen } \\
\text { at T10, then at } \mathrm{T} 8 \text {, for } 1 \text { month }\end{array}$ & $\mathrm{C} 3-\mathrm{C} 8$ & $\begin{array}{l}\text { Diminished touch, pressure, } \\
\text { and vibration below } \\
\text { elbows, mild weakness }\end{array}$ & $\begin{array}{l}\text { Diminished pain, vibration, } \\
\text { touch, and joint movement } \\
\text { sense below knees, Romberg } \\
\text { sign, ataxic gait }\end{array}$ \\
\hline $\begin{array}{l}3 \\
52 y / M\end{array}$ & $\begin{array}{l}\text { Nuchal pain and its } \\
\text { electrical radiation } \\
\text { to back }\end{array}$ & $\begin{array}{l}\text { Numbness and clumsiness of hands, } \\
\text { gait unsteadiness, tightness of } \\
\text { chest at } T 5 \text {, for } 6 \text { months }\end{array}$ & $\mathrm{C} 4-\mathrm{C} 8$ & $\begin{array}{l}\text { Diminished touch and } \\
\text { vibration below shoulders, } \\
\text { mild weakness }\end{array}$ & $\begin{array}{l}\text { Diminished pain below cervical } \\
\text { level, abolished vibration } \\
\text { below knees, weakness and } \\
\text { spasticity, Babinski sign, } \\
\text { frequent micturition }\end{array}$ \\
\hline $\begin{array}{l}4 \\
48\end{array}$ & $\begin{array}{l}\text { Numbness of finger } \\
\text { tips }\end{array}$ & $\begin{array}{l}\text { Dull aching around neck, clumsiness } \\
\text { of hands, weakness of right arm, } \\
\text { tightness of chest at T6, for } 32 \\
\text { months }\end{array}$ & C4-C6 & $\begin{array}{l}\text { Diminished touch and } \\
\text { vibration in hands, } \\
\text { acrocyanosis, weakness } \\
\text { and atrophy }\end{array}$ & $\begin{array}{l}\text { Diminished vibration, mild } \\
\text { spasticity }\end{array}$ \\
\hline $\begin{array}{l}5 \\
47 \mathrm{y} / \mathrm{M}\end{array}$ & $\begin{array}{l}\text { Numbness and } \\
\text { clumsiness of } \\
\text { hands }\end{array}$ & $\begin{array}{l}\text { Acrocyanosis (right), numbness below } \\
\text { knees, gait unsteadiness, tight band } \\
\text { at T8-9, for } 3 \text { months }\end{array}$ & $\mathrm{C} 6-\mathrm{C} 8$ & $\begin{array}{l}\text { Diminished touch and } \\
\text { vibration in hands; mild } \\
\text { weakness and spasticity, } \\
\text { acrocyanosis }\end{array}$ & $\begin{array}{l}\text { Diminished vibration and touch } \\
\text { in feet, mild spasticity, } \\
\text { Babinski sign }\end{array}$ \\
\hline $\begin{array}{l}6 \\
59 y / F\end{array}$ & $\begin{array}{l}\text { Dullness of neck } \\
\text { and shoulders }\end{array}$ & $\begin{array}{l}\text { Numbness and clumsiness of hands, } \\
\text { tight band at T6, numbness of } \\
\text { soles, for } 8 \text { months }\end{array}$ & $\mathrm{C} 4-\mathrm{C} 8$ & $\begin{array}{l}\text { Diminished touch and } \\
\text { vibration in hands, mild } \\
\text { weakness }\end{array}$ & $\begin{array}{l}\text { Diminished pain and vibration } \\
\text { below cervical level }\end{array}$ \\
\hline 75 y/M & $\begin{array}{l}\text { Numbness of palms } \\
\text { and soles }\end{array}$ & $\begin{array}{l}\text { Clumsiness of hands, gait } \\
\text { unsteadiness, tightness of chest } \\
\text { at T6, for } 36 \text { months }\end{array}$ & $\mathrm{C} 6-\mathrm{C} 8$ & $\begin{array}{l}\text { Diminished vibration in } \\
\text { hands }\end{array}$ & $\begin{array}{l}\text { Diminished pain below cervical } \\
\text { level, mild spasticity }\end{array}$ \\
\hline $\begin{array}{l}8 \\
76 y / F\end{array}$ & Gait unsteadiness & $\begin{array}{l}\text { Numbness of palms and soles, } \\
\text { clumsiness of hands, for } 12 \text { months }\end{array}$ & $\mathrm{C} 7-\mathrm{C} 8$ & Diminished touch in hands & $\begin{array}{l}\text { Ataxic gait, Romberg sign, } \\
\text { diminished vibration in feet, } \\
\text { Babinski sign }\end{array}$ \\
\hline
\end{tabular}

Figure 1 MRI and metrizamide CT of patient 2. (A) MRIs before (left) and after (right) discectomy, showing the level of cord compression. (B) Preoperative metrizamide CT at the C3-4 level shows massive compression of the cervical cord by a protruding soft disc. after surgery but considerable neurological deficits remained. Generalised hyporeflexia was converted to hyper-reflexia after decompression. For patient 4, the outcome for laminectomy from C3 to C7 with foraminectomy at C5-6 on the right was fair. The tight,

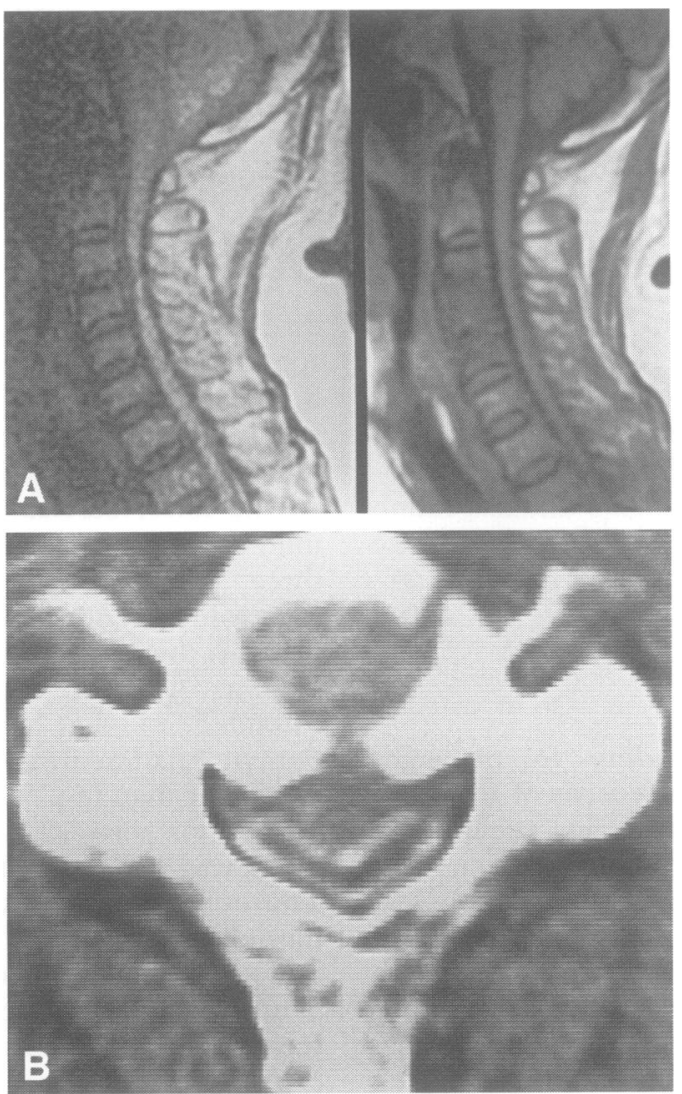

band like sensation at the midthoracic level disappeared in all the patients who underwent surgery.

\section{EXAMINATION OF PROPRIOCEPTIVE AND DISCRIMINATIVE HAND FUNCTIONS}

Proprioception in the hands was examined with respect to the sense of passive and active movements and position. ${ }^{7-9}$ The sense of passive movement was evaluated by the perception of the direction of movement given passively to the fingers. The sense of active movement was examined by the finger-to-nose test with the eyes open. The sense of position was evaluated with the eyes closed using the finger-to-nose test and the wandering of outstretched fingers (pseudoathetosis).

Tests of tactile discrimination included two point discrimination and graphaesthesia ${ }^{10}$ in the palms and finger tips. Stereoaesthesia ${ }^{11}$ was used to assess both proprioceptive and tactile discrimination in the hands. ${ }^{12}$ In the stereoaesthesia test, the ability to identify the shapes, consistencies, and textures of small objects, and dexterity in manipulating an object placed on the palm were evaluated.

\section{SOMATOSENSORY EVOKED POTENTIALS}

Somatosensory evoked potentials (SEPs) were recorded after median nerve stimulation at the wrist (median SEPs) with a connected ears reference. ${ }^{13}$ In addition, bipolar recordings of short latency SEPs ${ }^{14}$ were made. Recording electrodes on the scalp at $\mathrm{C} 3$ and $\mathrm{C} 4$ (the international 10-20 system), the seventh cervical spine (Cv7), and Erb's point were referenced to connected ears $(\mathrm{A}+)$. Antero- 


\begin{tabular}{|c|c|c|c|c|c|}
\hline Reflexes & $\begin{array}{l}\text { Horner's } \\
\text { syndrome }\end{array}$ & $\begin{array}{l}\text { C3-C4 discl } \\
\text { Spondylosis }\end{array}$ & Additional radiological findings & $\begin{array}{l}\text { Electrodiagnostic } \\
\text { findings }\end{array}$ & $\begin{array}{l}\text { Surgery and outcome } \\
\text { Postsurgical findings }\end{array}$ \\
\hline Normal & No & Massive/No & None & Normal EMG & $\begin{array}{l}\text { Anterior, excellent. } \\
\text { Tingling of finger tips }\end{array}$ \\
\hline $\begin{array}{l}\text { Decreased in } \\
\text { four limbs }\end{array}$ & No & Massive/No & $\begin{array}{l}\text { Venous angioma on the lumbar } \\
\text { ampulla }\end{array}$ & $\begin{array}{l}\text { EMG not done; } \\
\text { normal } \mathrm{H} \text { reflexes }\end{array}$ & $\begin{array}{l}\text { Anterior, fair. } \\
\text { Exaggerated reflexes, numbness and } \\
\quad \text { clumsiness, diminished pain from } \mathrm{C} 5 \text { to } \mathrm{C} 8\end{array}$ \\
\hline $\begin{array}{l}\text { Exaggerated } \\
\text { below C5 }\end{array}$ & Yes (left) & Massive/Yes & $\begin{array}{l}\text { C2-3 vertebral fusion; spondylotic } \\
\text { narrow canal at } C 5-6\end{array}$ & $\begin{array}{l}\text { Neurogenic EMG } \\
\text { in C5 }\end{array}$ & $\begin{array}{l}\text { Anterior, good. } \\
\text { Diminished touch and vibration in hands } \\
\text { without hypoalgesia, residual leg dysfunction }\end{array}$ \\
\hline $\begin{array}{l}\text { Decreased in } \\
\text { upper, and } \\
\text { increased in } \\
\text { lower limbs }\end{array}$ & $\begin{array}{l}\text { Yes } \\
\text { (bilateral) }\end{array}$ & Massive/Yes & $\begin{array}{l}\text { Narrow cervical canal; multiple } \\
\text { discs at C4-5 and C5-6 }\end{array}$ & $\begin{array}{l}\text { Neurogenic EMG } \\
\text { from } \mathrm{C} 5 \text { to } \mathrm{C} 7\end{array}$ & $\begin{array}{l}\text { Posterior, fair. } \\
\text { Numbness and clumsiness, } \\
\text { hypoalgesia in C6, diminished vibration in } \\
\text { hands and legs, weakness and atrophy in right } \\
\text { arm }\end{array}$ \\
\hline $\begin{array}{l}\text { Exaggerated } \\
\text { below } \mathrm{C} 5\end{array}$ & Yes (left) & Moderate/Yes & $\begin{array}{l}\text { Atlantoaxial dislocation without } \\
\text { cord compression }\end{array}$ & $\begin{array}{l}\text { Neurogenic EMG } \\
\text { in C5 }\end{array}$ & $\begin{array}{l}\text { Anterior, excellent. } \\
\text { Tingling of finger tips }\end{array}$ \\
\hline $\begin{array}{l}\text { Exaggerated } \\
\text { finger jerks }\end{array}$ & Yes (left) & Massive/Yes & $\begin{array}{l}\text { Mild canal stenosis from } \mathrm{C4}-5 \text { to } \\
\text { C6-7 }\end{array}$ & $\begin{array}{l}\text { Neurogenic EMG } \\
\text { from C5 to T1 }\end{array}$ & Not done \\
\hline $\begin{array}{l}\text { Exaggerated } \\
\text { below } \mathrm{C} 5\end{array}$ & Yes (right) & Moderate/Yes & $\begin{array}{l}\text { Narrow cervical canal; dynamic } \\
\text { dislocation at C5-6 }\end{array}$ & $\begin{array}{l}\text { Neurogenic EMG } \\
\text { in C8 }\end{array}$ & Not done \\
\hline $\begin{array}{l}\text { Exaggerated } \\
\text { below } C 7\end{array}$ & Yes (right) & Moderate/Yes & Narrow cervical canal & $\begin{array}{l}\text { Neurogenic EMG } \\
\text { in C5 }\end{array}$ & Not done \\
\hline
\end{tabular}

posterior bipolar leads connected $\mathrm{Cv} 7$ to the anterior neck just above the thyroid cartilage. Longitudinal bipolar leads connected Cv2 to a point $3 \mathrm{~cm}$ rostral to the inion. In the bipolar recordings, negativities at the posterior or caudal electrodes were shown upward. For the SEPs subsequent to posterior tibial nerve stimulation at the ankle (tibial SEPs), the recording electrodes were placed on the scalp at $\mathrm{Fz}, \mathrm{Cz}$, and $\mathrm{Pz}$ together with a connected ears reference, and on the 12 th thoracic spine (T12) with a reference on the iliac crest contralateral to the stimulated limb. ${ }^{15}$ Silver-silver chloride disc electrodes were attached to the skin, and the impedance maintained at less than 3000 ohms. Square wave pulses of $0.2 \mathrm{~ms}$ duration were delivered at the rate of four per second to a unilateral nerve trunk. The stimulus intensity was adjusted to produce a minimal twitch. Potentials were amplified and filtered between 10 and $1500 \mathrm{~Hz}$ ( $3 \mathrm{~dB}$ down). One thousand to 2000 epochs were averaged for an analysis time of $30 \mathrm{~ms}$ with a 2 ms delay between the shock and the sweep onset.

Somatosensory evoked potentials of age matched normal controls were obtained from 32 median nerves of 22 subjects (13 women and nine men) who had a mean age of 52.4 (range 38 to 74 ) years, and 17 tibial nerves of 16 subjects ( 11 women and five men) who had a mean age of 55.9 (range 38 to 81 ) years. Figure 2 shows median SEPs of a normal subject. The first small diphasic negative-positive wave with a positive peak (P10) and subsequent large negative wave (N13a) were identified in the anteroposterior bipolar leads. A large negative potential (N13b), identified in the longitudinal bipolar leads, had a peak latency similar to N13/P13 in SEPs with a connected ears reference. The absolute latencies of the median and tibial SEPs and the interpeak latency between lumbar N20 and scalp P37 in the tibial SEPs increased linearly in proportion to the subject's height.

\section{Results}

PROPRIOCEPTIVE AND DISCRIMINATIVE HAND FUNCTIONS (TABLE 2)

Sense of position was invariably impaired. The exploring hand wandered about and repeatedly missed the nose when the eyes

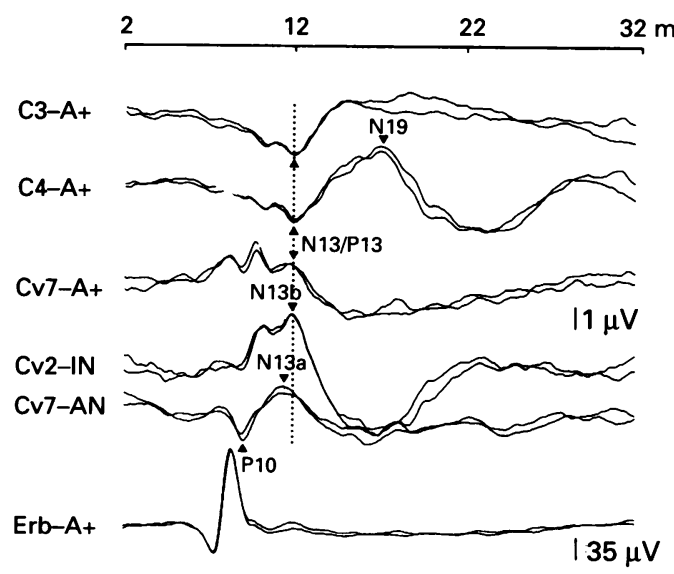

Figure 2 Median SEPs of a normal subject. P10, N13a, and N13b in the bipolar leads, and N13/P13 and N19 in the earlobe reference leads are shown by arrow heads. Vertical dashed lines represent the latencies of N13a and $N 13 b$ in this figure and in figures 3 and 4. 
Table 2 Hand dysfunction

\begin{tabular}{|c|c|c|c|c|c|c|c|}
\hline \multirow[b]{2}{*}{ Patient/age/sex } & \multicolumn{3}{|l|}{ Position } & \multicolumn{3}{|c|}{ Discriminative functions } & \multirow[b]{2}{*}{$\begin{array}{l}\text { Dexterity of } \\
\text { manipulation }\end{array}$} \\
\hline & $\begin{array}{l}\text { FNT with } \\
\text { eyes closed }\end{array}$ & $\begin{array}{l}\text { Pseudo- } \\
\text { athetosis }\end{array}$ & $\begin{array}{l}\text { Passive } \\
\text { movement }\end{array}$ & Two point & $\begin{array}{l}\text { Graphaes- } \\
\text { thesia }\end{array}$ & $\begin{array}{l}\text { Stereo- } \\
\text { aesthesia }\end{array}$ & \\
\hline $\begin{array}{l}1 / 53 / \mathrm{F} \\
2 / 58 / \mathrm{M} \\
3 / 52 / \mathrm{M} \\
4 / 48 / \mathrm{F} \\
5 / 47 / \mathrm{M} \\
6 / 59 / \mathrm{F} \\
7 / 55 / \mathrm{M} \\
8 / 76 / \mathrm{F}\end{array}$ & $\begin{array}{l}2^{\star} \\
2 \\
2^{\star} \\
2 \\
1^{\star} \\
2 \\
1 \\
1\end{array}$ & $\begin{array}{l}\text { Yes } \\
\text { Yes } \\
\text { Yes } \\
\text { Yes } \\
\text { No } \\
\text { Yes } \\
\text { No } \\
\text { No }\end{array}$ & $\begin{array}{l}0 \\
2^{\star} \\
1^{\star} \\
2^{\star} \\
0 \\
1 \\
0 \\
0\end{array}$ & $\begin{array}{l}1^{\star} \\
2 \\
1 \\
2 \\
1 \\
2 \\
1 \\
1\end{array}$ & $\begin{array}{l}0 \\
1^{\star} \\
1^{\star} \\
1^{\star} \\
0 \\
1 \\
0 \\
0\end{array}$ & $\begin{array}{l}2^{\star} \\
2 \\
2^{\star} \\
2 \\
1^{\star} \\
2 \\
1 \\
1\end{array}$ & $\begin{array}{l}2^{\star} \\
2 \\
2^{\star} \\
2 \\
2^{\star} \\
2 \\
1 \\
1\end{array}$ \\
\hline
\end{tabular}

*Signs profoundly diminished after surgery; FNT = finger-to-nose test; $0=$ normal; $1=$ mildly impaired; $2=$ severely impaired or lost.

were closed. Five patients who had severe target pointing errors also had pseudoathetosis. Perception of passive movement and target pointing with the eyes open were less affected. In the discriminative sensory functions, loss of stereoaesthesia was remarkable by contrast with the relative preservation of two point and tactile directional discrimination. Two point discrimination was possible at distances of 5 to $10 \mathrm{~mm}$ on the finger tip and 20 to $30 \mathrm{~mm}$ on the palm in the mildly impaired patients.

Recognition of numerical symbols outlined on the finger tips or palms was possible, occasional errors being made by the mildly impaired patients.

As well as the inability to identify small objects, dexterity of manipulation was impaired. The patients had difficulty in bringing an object into a position between the index finger and thumb, the manner by which normal subjects identify such objects. ${ }^{16}$ They clenched and opened the fist, and pressed the object to the palm using the fingers, but with no rolling of the thumb and index fingers. They sometimes lost the object but continued their exploring movements, perception of the given tactile stimuli being preserved. Awkwardness of manipulation was an essential feature of their hand clumsiness.

SOMATOSENSORY EVOKED POTENTIALS

In the median SEPs, the absolute latencies of Erb's potential and P10 in the anteroposterior bipolar lead (figs 3 and 4) adjusted to $160.0 \mathrm{~cm}$ were always within the normal means plus 3 SD. Table 3 shows interpeak

Figure 3 Median SEPs in patient 7. N13b and subsequent components are delayed. All the components except Erb's potential and the first diphasic wave in $C v 7-A+$ and Cv7-AN leads have low amplitudes.

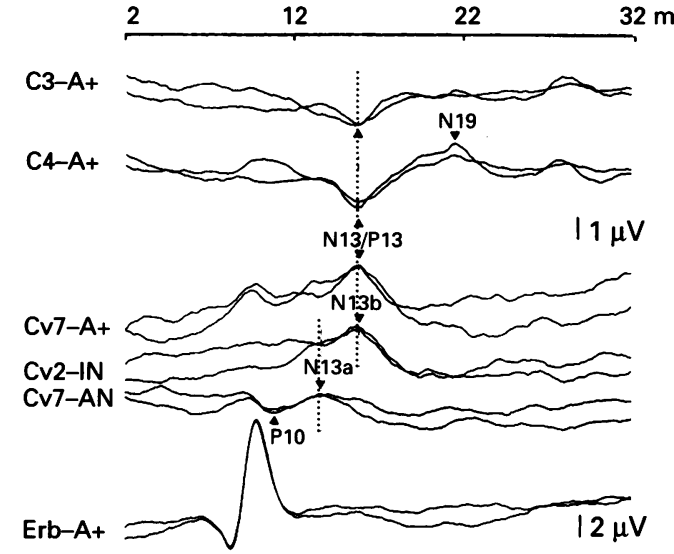

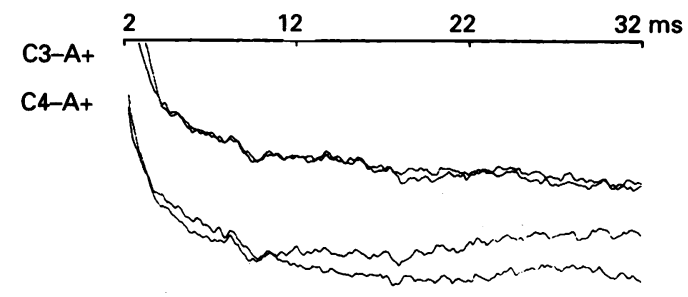
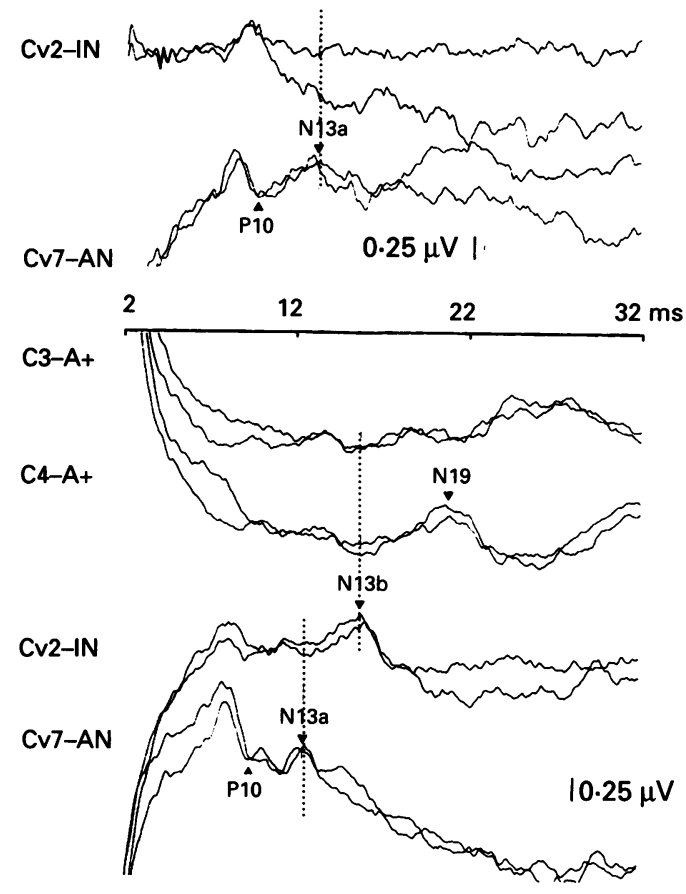

Figure 4 Median SEPs in patient 2 before (top) and after (bottom) surgery. P10 and N13a of low amplitudes are present with no subsequent activities (top). After discectomy, small, delayed N13b and N19 are present and $N 13$ a remains low in amplitude (bottom). In Cv7-AN leads, the first diphasic wave is larger than subsequent N13a.

latencies of N13a and N13b from P10, and of $\mathrm{N} 19$ from N13b. In the preoperative recordings, although P10 was always identified, N13a, N13b, and N13/P13 were occasionally absent. In patient $2, \mathrm{~N} 13 \mathrm{a}$ was present but without identifiable $\mathrm{N} 13 \mathrm{~b}$ and scalp potentials (fig 4 top). In the other recordings showing both N13a and N13b, the prolonged P10$\mathrm{N} 13 \mathrm{~b}$ interpeak latency was remarkable in comparison with the normal P10-N13a interpeak latency. N19 evoked in the scalp electrodes contralateral to the stimulus side was attenuated (figs 3 and 4 bottom) or 
Table 3 Interpeak latencies of somatosensory evoked potentials

\begin{tabular}{|c|c|c|c|c|c|c|c|c|}
\hline \multirow{3}{*}{$\begin{array}{l}\text { Patient/ } \\
\text { Height }\end{array}$} & \multicolumn{6}{|c|}{ Median SEPs (ms) } & \multirow{2}{*}{\multicolumn{2}{|c|}{$\frac{\text { Tibial SEPs (ms) }}{N 20-P 37^{\star}}$}} \\
\hline & \multicolumn{2}{|c|}{$P 10-N 13 a$} & \multicolumn{2}{|c|}{$P 10-N 13 b$} & \multicolumn{2}{|c|}{$N 13 b-N 19$} & & \\
\hline & Left & Right & Left & Right & Left & Right & Left & Right \\
\hline $1 / 152 \cdot 5$ & \multirow{3}{*}{$\begin{array}{c}2 \cdot 64 \\
(2 \cdot 82) \\
3 \cdot 18 \\
(3 \cdot 38) \\
-(3 \cdot 18)\end{array}$} & $\begin{array}{c}2 \cdot 82 \\
(3 \cdot 00)\end{array}$ & $\begin{array}{c}7 \cdot 44 \\
(4 \cdot 08)\end{array}$ & $\begin{array}{c}7 \cdot 14 \\
(4 \cdot 14)\end{array}$ & $\begin{array}{c}5 \cdot 52 \\
(5 \cdot 70)\end{array}$ & $\begin{array}{c}6.06 \\
(6.00)\end{array}$ & $16 \cdot 0$ & \\
\hline $2 / 159 \cdot 0$ & & $(3 \cdot 66)$ & $\frac{-}{(6 \cdot 60)}$ & $(5.94)$ & $(6 \cdot 24)$ & $(6 \cdot 36)$ & \multirow[t]{2}{*}{$\begin{array}{c}25 \cdot 0 \\
(21 \cdot 1)\end{array}$} & \\
\hline $3 / 168 \cdot 2$ & & $\begin{array}{c}3.66 \\
(2.58)\end{array}$ & & $\begin{array}{c}7.02 \\
(5 \cdot 64)\end{array}$ & $\begin{array}{l}0 \\
(6 \cdot 36)\end{array}$ & $\begin{array}{r}6 \cdot 66 \\
(5 \cdot 70)\end{array}$ & & \\
\hline $4 / 148 \cdot 8$ & \multirow{2}{*}{$\begin{array}{c}- \\
(2.70) \\
3.00 \\
(3.00) \\
2 \cdot 28 \\
3.00 \\
2.76\end{array}$} & \multirow{2}{*}{$\begin{array}{c}(2 \cdot 58) \\
2 \cdot 52 \\
(2 \cdot 70) \\
2 \cdot 22 \\
2 \cdot 76\end{array}$} & $(3.96)$ & $(7 \cdot 80)$ & $(5 \cdot 79)$ & $(5 \cdot 89)$ & \multicolumn{2}{|l|}{$(19 \cdot 3)$} \\
\hline $\begin{array}{l}6 / 154 \cdot 0 \\
7 / 166 \cdot 6 \\
8 / 147 \cdot 0\end{array}$ & & & $\begin{array}{c}5.58 \\
(3.84) \\
6.00 \\
4.98 \\
6.24\end{array}$ & $\begin{array}{c}(4 \cdot 02) \\
5 \cdot 46 \\
5 \cdot 46\end{array}$ & $\begin{array}{c}6.55 \\
(6.72) \\
- \\
6.36 \\
5.94\end{array}$ & $\begin{array}{c}(6 \cdot 18) \\
6 \cdot 18 \\
5.94\end{array}$ & $\begin{array}{c}(18 \cdot 0) \\
19 \cdot 1 \\
20 \cdot 6 \\
21.9\end{array}$ & $\begin{array}{c}(18 \cdot 2) \\
20 \cdot 2\end{array}$ \\
\hline $\begin{array}{l}\text { Normal values: } \\
\text { Mean (SD) } \\
\text { Upper limits } \dagger\end{array}$ & \multicolumn{2}{|c|}{$\begin{array}{l}2.64(0.35) \\
3.69\end{array}$} & \multicolumn{2}{|c|}{$\begin{array}{l}3.03(0.43) \\
4.32\end{array}$} & \multicolumn{2}{|c|}{$\begin{array}{l}5 \cdot 94(0.47) \\
7 \cdot 35\end{array}$} & \multicolumn{2}{|c|}{$\begin{array}{l}17 \cdot 1(1 \cdot 27) \\
20 \cdot 9\end{array}$} \\
\hline
\end{tabular}

$\star \mathrm{N} 20-\mathrm{P} 37 \mathrm{IPL}$ is adjusted to $160.0 \mathrm{~cm}$; its normal value is at that height; $\nmid$ Normal mean $+3 \mathrm{SD}$. Values for SEPs after surgery are given in parentheses. $-=\mathrm{The}$ later components (N13a, N13b, or N19) were not evoked.

Figure 5 Preoperative (closed circles) and postoperative (open circles) P10-N13a amplitude values for median SEPs. Data on left stimulation are arranged on the left of each patient's number. Data on the zero line show that no N13a was evoked. The stippled area indicates the normal limits within 2 $S D$ from the mean.

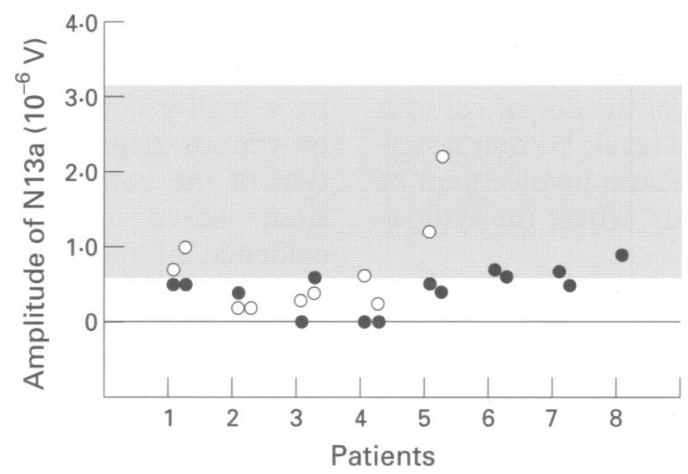

absent (fig 4 top), but when present had a normal interpeak latency from cervical N13b. Postoperatively, N13a, N13b, and N19 were evoked in all the nerves tested (fig 4 bottom). In each patient who had prolonged preoperative $\mathrm{P} 10-\mathrm{N} 13 \mathrm{~b}$ interpeak latencies, the interpeak latency was shortened and had normal values in patients 1 and 5 .

The peak to peak amplitude of N13a from P10 (P10-N13a amplitude) was low in both the preoperative and postoperative periods, except for a significant postoperative increase in patient 5 (fig 5). When the absolute amplitude of P10-N13a was low, the amplitude ratio of P10-N13a to the first diphasic wave ${ }^{17}$ was low as well (figs 3 and 4). In the tibial SEPs, the lumbar potential (N20) and scalp P37 were evoked. The N20-P37 interpeak latency was normal or mildly prolonged in all the nerves tested (table 3).

\section{Discussion}

The eight patients with chronic cervical cord compression at the C3-4 intervertebral level had stereotypical clinical manifestations. Dissociated impairment of the upper and lower limbs, of the proprioceptive and discriminative senses in the upper limbs, and the sense of vibration and other functions in the lower limbs were pronounced. Numbness in the palms and finger tips, and occasionally in the soles, was an early symptom. A tight, band like sensation at the midthoracic level was a notable complaint.

Hand dysfunction without significant involvement of the lower limbs is an outstanding feature of cervical spondylotic myelopathies. The SEPs showed more prominent abnormalities after median stimulation than after tibial stimulation. The cervical N13 in the median SEPs has at least two separate generators, ${ }^{14}$ one of which originates low in the cervical cord. ${ }^{1718}$ On the basis of results of bipolar recordings, Kaji and Sumner ${ }^{14}$ divided cervical N13 into N13a of lower cervical cord origin and $\mathrm{N} 13 \mathrm{~b}$ of medullary origin. Their technique showed that the P10-N13a interpeak latencies were normal and the P10$\mathrm{N} 13 \mathrm{~b}$ interpeak latencies greatly prolonged with attenuated or absent scalp potentials in our patients. The interpeak latencies of $\mathrm{N13b}$ were reduced after decompressive surgery and accompanied regenerated scalp potentials. These findings, which suggest conduction failure through the fasciculus cuneatus, are compatible with a cord lesion level at the C3-4 disc, which is of the C4 or C5 cord segment. ${ }^{19-21}$ By contrast, conduction through the fasciculus gracilis is relatively preserved, as shown by the normal or mildly increased N20-P37 interpeak latencies.

Clumsiness of the hands is an early manifestation of, and a cardinal sign in, the syndrome. In proprioceptive modalities, the sense of position in the upper limbs-most evident in the hands-was affected. Impairment of proprioception is responsible for the clumsiness shown by the uncoordinated handling of a small object with the eyes closed in the test of stereoaesthesia. Stereoaesthesia itself may be caused by disturbances of active touch and proprioception. ${ }^{12}{ }^{22}{ }^{23} \mathrm{By}$ contrast, tactile discrimination of passively given stimuli, graphaesthesia in particular, is relatively preserved. A similar dissociation between stereoaesthesia and graphaesthesia in high cervical cord disorders has been described by Boshes and Padberg. ${ }^{11}$

Functional lamination of the dorsal 
columns has been shown in animal experiments ${ }^{24}$ and human studies, ${ }^{25}$ as reviewed by Ross. ${ }^{26}$ These studies suggest that the discrimination of given tactile stimuli is anatomically related to the outermost layer of the dorsal column, vibration sense to the innermost layer close to the commisure, and proprioception to the area between them. In our patients, sensory dissociation in the hands denoted lesion localisation in the inner aspect of the fasciculi cuneati. According to the topographical anatomy of the human dorsal column established by Smith and Deacon, ${ }^{27}$ the fasciculus cuneatus occupies most of the ventral aspect of the column adjacent to the commisure from the second to sixth cervical cord segment. The proposed lesion in the inner aspect of the dorsal column may affect the innermost part of the fasciculi graciles that is responsible for vibration, but spare the middle part responsible for proprioception within the fasciculi.

In conclusion, our patients' various dissociated forms of impairment are explained by a lesion to the inner aspect of the dorsal column at the C3-4 intervertebral level. Horner's syndrome in six patients indicates involvement of the deeper lateral funiculus, where the sympathetic tract descends. ${ }^{28}$

Numbness at the distal ends of the upper limbs, sometimes associated with numbness of the lower limbs, is the earliest manifestation of illness. Tingling in the finger tips remained in two patients who had excellent surgical outcomes. In general, the initial symptom has a localising value; therefore, the probable site of the lesion responsible for the paraesthesiae is in the cervical cord at C3-4. This peripheral neuropathy type sensory presentation is well recognised but ill defined in cervical spondylotic myelopathy. The band like tightness with the character of deep pain at the thoracic cord level was a later complaint, which disappeared after surgery. Schvarcz ${ }^{29}$ stimulated the base of the dorsal columns of conscious patients at the cervicomedullary junction and obtained a basic response pattern that consisted of paraesthesiae starting at the soles of both feet. In a stimulation study, bilateral burning truncal sensations were sometimes described when "the central canal region" was stimulated. ${ }^{30}$ Involvement of the dorsal column or afferent propriospinal fibres explains these caudal sensory phenomena. The somatotopic organisation of the dorsal column at a higher cervical cord level ${ }^{31}$ accounts for the paraesthesiae of the extremities. The propriospinal system within the central grey matter or in the perigriseal white matter that connects the different segments of the body ${ }^{32} 3$ probably contributes to truncal tightness.

Whether there is profound and enduring impairment of motor acts after dorsal cordotomy is a matter of controversy. ${ }^{1234}$ In our patients dysfunctions within the grey matter contributed to some manifestations. Diminished pain and temperature sense, neurogenic changes in electromyography extending to the lower cervical segments, and decreased amplitudes of the lower cervical P10-N13a indicate the involvement of the cord caudal to C3-4. These findings for patients 1,2 , and 5 , who showed no lower spondylotic changes, are strong evidence of lower grey matter involvement due to higher cord compression. Dysfunctions of the dorsal grey matter may also contribute to hand clumsiness. There are propriospinal neurons in cats that function in forelimb target reaching that are located in the cervical cord at $\mathrm{C} 3$ and $\mathrm{C} 4$, called "C3-C4 propriospinal neurons". ${ }^{35}$ The propriospinal system is considered to receive impulses from both cutaneous and group I muscle afferents, and their deafferentation results in hypermetria in forelimb target reaching. ${ }^{36}{ }^{37}$ In primate experiments, dorsal column lesion extending to the neighbouring grey matter or the pericanal region at the C3-4 level was shown to impair motor performance. ${ }^{38} 39$

Central cord involvement due to compressive myelopathy $y^{40}$ has been explained as being caused by border zone arterial insufficiency, ${ }^{41}$ or by direct compressive and shearing forces. ${ }^{42}$ Caudal involvement of the grey matter caused by a higher compression has been explained by venous stagnation, ${ }^{43}$ or dynamic propagation of the compressive force. ${ }^{44}$ Our conclusion, based on clinicoelectrophysiological evidence of the transverse and longitudinal extents of the lesion, is that involvement of the central cord and its caudal extension, which is caused by high cervical compression at the C3-4 intervertebral level, is responsible for the syndrome.

We thank Dr Seisuke Watanabe for his advice on the SEP techniques, and Dr Mitsuru Kawamura for the referral of patient 2 . We also deeply appreciate the suggestions made by Dr Ryuji Kaji, Department of Neurology, Faculty of Medicine, Kyoto University.

1 Daniels LE. Compression of cervical portion of the spinal cord. Neurology 1956;6:344-9.

2 Good DC, Couch JM, Wacaser L. "Numb, clumsy hands" and high cervical spondylosis. Surg Neurol 1984;22: 285-91.

3 Savettieri G, Castiglione MG, D'Arpa A, Aiello S, Fierro B. Loss of joint position sense with sparing of vibration sense in two cases of compressive cervical myelopathy. Acta Neurol (Napoli) 1984;6:11-5.

4 England JD, Hsu CY, Vera CL, Barone BM, Rawe SE. Spondylotic high cervical compression presenting with hand complaints. Surg Neurol 1986;25:299-303.

5 Voskuhl RR, Hinton RC. Sensory impairment in the hands secondary to spondylotic compression of the cervihands secondary to spondylotic compression
cal spinal cord. Arch Neurol 1990;47:309-11.

6 Nakajima M, Hirayama K. High cervical disc herniation presenting with deep sensory disturbances of the upper limbs. Shinkei Kenkyu no Shinpo (fapan) 1993;37: 235-44. (In Japanese.)

7 McCloskey DI. Kinesthetic sensibility. Physiol Rev 1978;58:763-820.

8 Gandevia SC. Neurophysiological mechanisms underlying proprioceptive sensations. In: Struppler A, Weindl A, eds. Clinical aspects of sensory motor integration. Berlin: Springer-Verlag, 1987:14-24.

9 Adams RD, Victor M. Principles of neurology. 5th ed. New York: McGraw-Hill, 1993:138-9.

10 Bender MB, Stacy C, Cohen J. Agraphesthesia: a disorder of directional cutaneous kinesthesia or disorientation in cutaneous space. $\mathcal{F}$ Neurol Sci 1982;53:531-55.

11 Boshes B, Padberg F. Studies on the cervical spinal cord in man: sensory patterns after interruption of the posterior man: sensory patterns after interrup
columns. Neurology 1953;3:90-101.

12 Vierck CJ, Jr. The spinal lemniscal pathways. In: Davidoff RA, ed. Handbook of the spinal cord. Vols 2 and 3. New RA, ed. Handbook of the spinal cord. Vol

13 Yamada T, Kimura J, Nitz DM. Short latency somatosensory evoked potentials following median nerve stimulation in man. Electroencephalogr Clin Neurophysiol 1980;48:367-76.

14 Kaji R, Sumner AJ. Bipolar recording of short-latency somatosensory evoked potentials after median nerve stimulation. Neurology 1987;37:410-8.

15 Chiappa KH. Short-latency somatosensory evoked poten- 
tials: Methodology. In: Chiappa $\mathrm{KH}$, ed. Evoked potential in clinical medicine. New York: Raven Press, 1990: 308-70.

16 Pause $M$, Kunesch E, Binkofski F, Freund HJ Sensorimotor disturbances in patients with lesions of the parietal cortex. Brain 1989;112:1599-625.

17 Mauguière F, Restuccia D. Inadequacy of the forehead reference montage for detecting abnormalities of the spinal N13 SEP in cervical cord lesions. Electroencephalogr Clin Neurophysiol 1991;79:448-56.

18 Desmedt JE, Cheron G. Prevertebral (oesophageal) recording of subcortical somatosensory evoked potentials in man: the spinal P13 component and the dual nature of the spinal generators. Electroencephalogr Clin Neurophysiol 1981;52:257-75.

19 Payne EE, Spillane JD. The cervical spine: an anatomico pathological study of 70 specimens (using a special technique) with particular reference to the problem of cervical nique) with particular reference to the

20 Mair WGP, Druckman R. The pathology of spinal cord lesions and their relation to the clinical features in protrusion of cervical intervertebral discs: a report of four cases. Brain 1953;76:70-91.

21 Wilkinson $M$. The morbid anatomy of cervical spondylosis and myelopathy. Brain 1960;83:589-617.

22 Gibson JJ. Observations on active touch. Psychol Rev 1962;69:477-91

23 Brinkman J, Porter R. Movement performance and afferent projections to the sensorimotor cortex in monkeys with dorsal column lesions. In: Gordon G, ed. Active touch. Oxford: Pergamon Press, 1978:119-37.

24 Uddenberg N. Differential localization in dorsal funiculus of fibres originating from different receptors. Exp Brain Res 1968;4:367-76.

25 Schneider RC. Syringomyelia. In: Schneider RC, Khan EA, Crosby EC, Taren JA, eds. Correlative neurosurgery. 3rd ed. Springfield: Charles C Thomas, 1982:1022.

26 Ross RT. Dissociated loss of vibration, joint position and discriminatory tactile senses in disease of spinal cord and brain. Can $\mathcal{F}$ Neurol Sci 1991;18:312-20.

27 Smith MC, Deacon P. Topographical anatomy of the posterior columns of the spinal cord in man. Brain 1984; 10:671-98.

28 Nathan PW, Smith MC. The location of descending fibres to sympathetic neurons supplying the eye and sudomotor neurons supplying the head and neck 7 Neurol Neurosurg Psychiatry 1986;49:187-94.
29 Schvarcz JR. Stereotactic extralemniscal myelotomy. F Neurol Neurosurg Psychiatry 1976;39:53-7.

30 Schvarcz JR. Functional exploration of the spinomedullary junction. Acta Neurochirurgica (suppl) 1977; 24:179-85.

31 Whitsel BL, Petrucelli LM, Sapiro G, Ha H. Fiber sorting in the fasciculus gracilis of squirrel monkeys. Exp Neurol 1970;29:227-42.

32 Nathan PW, Smith MC. Fasciculi proprii of the spinal cord in man. Brain 1959;82:610-68.

33 Cook AW, Nathan PW, Smith MC. Sensory consequences of commisural myelotomy: A challenge to traditional anatomical concepts. Brain 1984;107:547-68.

34 Davidoff RA. The dorsal columns. Neurology 1989;39: 1377-85.

35 Illert $M$, Lundberg $A$, Tanaka $R$. Integration in the descending motor pathways controlling the forelimb in the cat: 3 . convergence on propriospinal neurones transmitting disynaptic excitation from the corticospinal tract and other descending tracts. Exp Brain Res 1977;29: and other.

36 Alstermark B, Gorska T, Johannisson T, Lundberg A. Hypermetria in forelimb target-reaching after interruption of the inhibitory pathway from forelimb afferents to C3-C4 propriospinal neurones. Neurosci Res 1986;3: 457-61.

37 Kitazawa S, Urushihara Y, Hongo T. Forelimb skin deafferentation impaired limb movements in the cat Neurosci Res (suppl) 1991;16:104.

38 Ferraro A, Barrerra SE. Effects of experimental lesions of the posterior columns in macacus rhesus monkeys. Brain 1934;57:307-32.

39 Gilman S, Denny-Brown D. Disorders of movement and behaviour following dorsal column lesions. Brain 1966; 89:397-418.

40 Crandall PH, Batzdorf U. Cervical spondylotic myelopathy. $\mathcal{F}$ Neurosurg 1966;25:57-68.

41 Turnbull IM, Brieg L, Hassler C. Blood supply of cervical spinal cord in man: a microangiographic cadaver study. f Neurosurg 1966;24:951-65.

42 Panjabi $M$, White A. Biomechanics of nonacute cervical spinal cord trauma. Spine 1988;13:838-42.

43 Taylor AR, Byrnes DP. Foramen magnum and high cervical cord compression. Brain 1974;97:473-80.

44 Hashizume Y, Iijima S. Pencil-shaped softening of the spinal cord: pathologic study in 12 autopsy cases. Acta Neuropathol (Berl) 1983;61:219-24. 